\section{Migrastatin, a Novel 14-Membered Ring Macrolide, Inhibits Anchorage-independent Growth of Human Small Cell Lung Carcinoma Ms-1 Cells}

\author{
YASUSHI TAKEMOTO ${ }^{\dagger}$, KOICHI NAKAE ${ }^{\dagger}$, MAKOTO KaWATANI $^{\dagger}$, \\ YOSHIKAZU TAKAHASHI ${ }^{\dagger \dagger}$, HiROSHI NAGANAWA ${ }^{\dagger \dagger}$ \\ and MASAYA IMOTO $* *$ \\ ${ }^{\dagger}$ Department of Applied Chemistry, Faculty of Science and \\ Technology, Keio University, \\ 3-14-1 Hiyoshi, Kohoku-ku, Yokohama 223-8522, Japan \\ ${ }^{+\dagger}$ Institute of Microbial Chemistry, \\ 3-14-23 Kamiosaki, Shinagawa-ku, Tokyo 141-0021, Japan
}

(Received for publication July 17, 2001)

In a previous study, we reported a novel 14-membered ring macrolide, migrastatin isolated from culture broth of Streptomyces sp. MK929-43F1 as an inhibitor of tumor cell migration ${ }^{1)}$. Recently, however, we found that our original migrastatin isolate contained teleocidin-related compounds which display strong inhibitory activity against tumor cell migration. In this report, we describe the effects of teleocidin-free migrastatin on tumor cell migration and on the growth of several types of tumor cells.

When the original migrastatin sample was subjected to HPLC (Capcell Pak $\mathrm{C}_{18}$ column, $20 \times 250 \mathrm{~mm}$ ) developing with $70 \%$ aq acetonitrile, a potent migration inhibitory activity was eluted in a fraction other than migrastatin, indicating that the migration inhibitory activity of our original migrastatin samples reported previously was due to the activity of an impurity. The potent migration inhibitory fraction contained teleocidin-related compounds, as judged from UV spectrum. Teleocidin-related compounds are known to inhibit $\left[{ }^{3} \mathrm{H}\right] \mathrm{PDBu}$ binding to the cell surface ${ }^{2)}$, therefore, we clarified the content of teleocidin-related compounds in the original migrastatin sample as evaluated by $\left.{ }^{3} \mathrm{H}\right] \mathrm{PDBu}$ binding assay (Fig. 1). The findings indicate that the original migrastatin contained about $0.1 \%$ teleocidin-related compounds. The major component $(7 \mu \mathrm{g}$, as estimated by absorbance at $227 \mathrm{~nm}$ ) was isolated from $29.3 \mathrm{mg}$ of original migrastatin samples by HPLC (Capcell Pak $\mathrm{C}_{18}$ column, $20 \times 250 \mathrm{~mm}$ ) developing with $54 \%$ aq acetonitrile. 'H-NMR, UV and mass spectral data suggested that this major component was identical to pendolmycin ${ }^{3)}$. On the other hand, migrastatin separated by HPLC did not significantly inhibit $\left[{ }^{3} \mathrm{H}\right] \mathrm{PDBu}$ binding to the cell surface up to $100 \mu \mathrm{g} / \mathrm{ml}$, indicating that the migrastatin thus obtained can be used for biological studies. In addition, the physico-chemical properties of migrastatin thus obtained did not differ from those of original migrastatin reported previously ${ }^{4)}$, possibly due to the low content of impurities.

Migration inhibitory activities of pure migrastatin and pendolmycin were assayed by the wound healing method as described before ${ }^{1)}$. In brief, a standardized scratch was made through a confluent monolayer of human esophageal carcinoma $\mathrm{EC} 17$ cells, and then the cells from the cut edge were allowed to migrate for 24 hours $^{5}$. Pendolmycin as well as teleocidin B inhibited migration of EC17 cells at $10 \mathrm{ng} / \mathrm{ml}$ (data not shown). On the other hand, EC17 cells migrated inwardly and covered a great area of the scratch even in the presence of $100 \mu \mathrm{g} / \mathrm{ml}$ of migrastatin. However, when the EC17 cells were pretreated with migrastatin

Fig. 1. Effect of migrastatin on $\left[{ }^{3} \mathrm{H}\right] \mathrm{PDBu}$ binding.

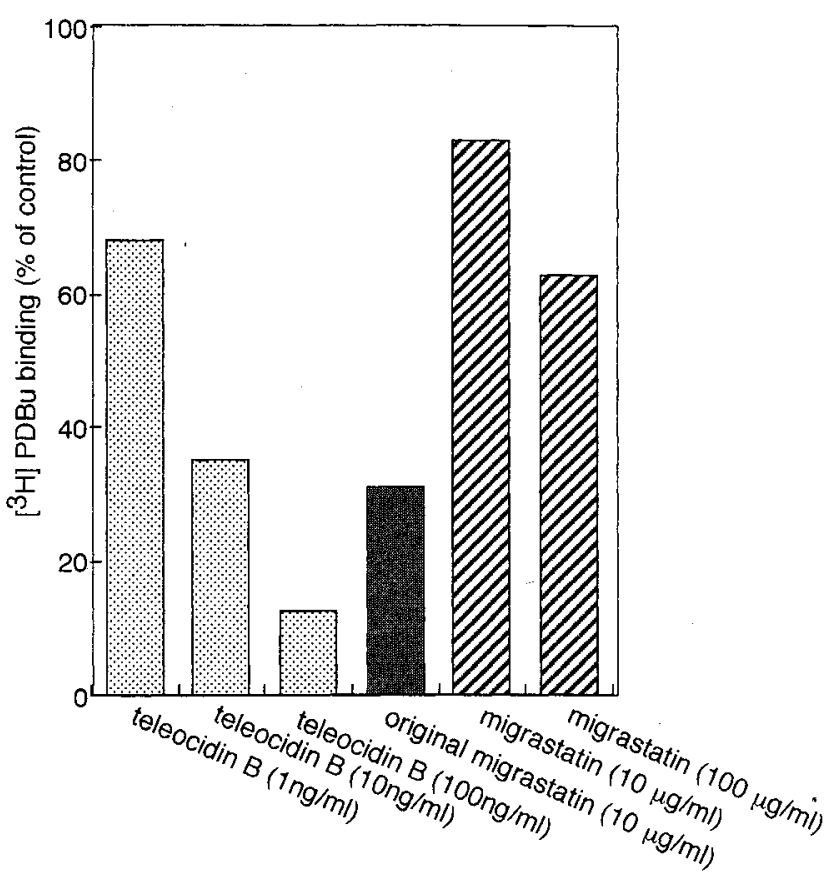

B16BL6 C-2 cells were incubated with $8.3 \mathrm{nCi}$ of $\left[{ }^{3} \mathrm{H}\right] \mathrm{PDBu}$ and chemicals for 30 minutes at $37^{\circ} \mathrm{C}$. Then, cells were collected and radioactivity was measured by a liquid scintillation counter

* Corresponding author: imoto@applc.keio.ac.jp 
Fig. 2. Effect of migrastatin on EC17 cell migration by wound healing assay.

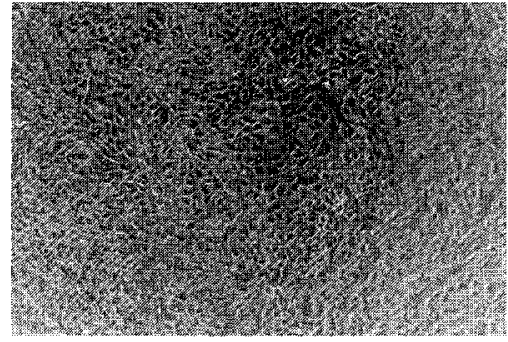

Migrastatin $(0 \mu \mathrm{g} / \mathrm{ml})$

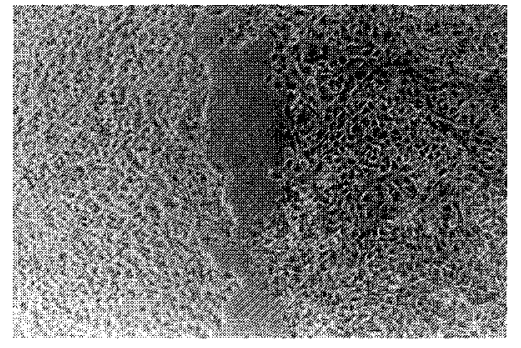

Migrastatin $(10 \mu \mathrm{g} / \mathrm{ml})$

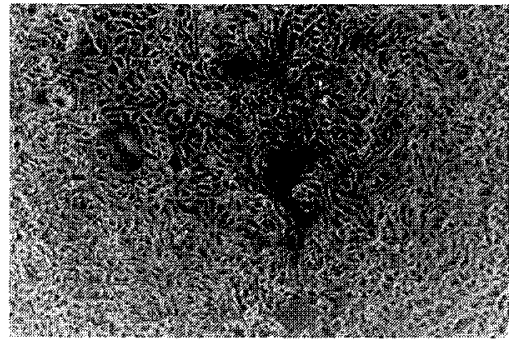

Migrastatin $(3 \mu \mathrm{g} / \mathrm{ml})$

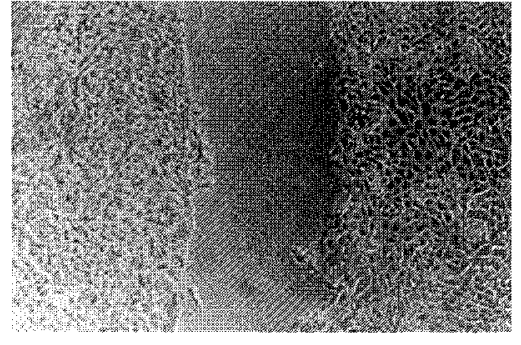

Migrastatin $(30 \mu \mathrm{g} / \mathrm{ml})$

Confluent cultures of EC17 cells were pre-treated with migrastatin for 24 hours, then a wound was introduced The cells were further incubated in the presence of migrastatin. After 24 hours, the cells were photographed under phase-contrast microscopy.

for 24 hours before scratching, $10 \mu \mathrm{g} / \mathrm{ml}$ of migrastatin significantly inhibited the migration of EC17 cells, and $30 \mu \mathrm{g} / \mathrm{ml}$ of migrastatin completely inhibited cell migration as judged from the residual area between the inwardly migrating EC17 cells from the edges of the scratch (Fig. 2). Migrastatin inhibited migration of $\mathrm{EC} 17$ cells with an $\mathrm{IC}_{50}$ value of about $10 \mu \mathrm{g} / \mathrm{ml}$, but it inhibited cell proliferation of EC17 cells with an $\mathrm{IC}_{50}$ value of $82 \mu \mathrm{g} / \mathrm{ml}$ (Table 1), and it failed to induce cell death in EC17 cells up to $100 \mu \mathrm{g} / \mathrm{ml}$. These results indicated that inhibition of migration of EC17 cells by migrastatin should not be due to the inhibition of cell proliferation or induction cell death by the drug. One $\mathrm{ng} / \mathrm{ml}$ of pendolmycin did not inhibit migration even with 24 hours pretreatment. Additionally, erythromycin and clarithromycin, other 14-membered ring macrolides, did not inhibit migration of EC17 cells up to $100 \mu \mathrm{g} / \mathrm{ml}$.

Next we examined the effect of migrastatin on cell proliferation. Various types of cultured cells were treated with migrastatin, and after 72 hours, their cell numbers were determined by MTT assay. As shown in Table 1, inhibitory activity of migrastatin on cell proliferation depended on the cell type. Migrastatin did not affect the growth rate of normal fibroblasts including Rat 1, Rat 6,
Table 1. Effect of migrastatin on the growth of various cultured cells.

\begin{tabular}{|l|c|}
\hline \multicolumn{1}{|c|}{ Cell line } & $\mathrm{IC}_{50}[\mu \mathrm{g} / \mathrm{ml}]$ \\
\hline Rat 1 (rat fibroblast) & $>100$ \\
\hline Rat6 (rat fibroblast) & $>100$ \\
\hline NIH 3T3 (mouse fibroblast) & $>100$ \\
\hline raf NIH3T3 & 64 \\
\hline v-Ha-ras NIH3T3 & 48 \\
\hline 3Y1 (mouse fibroblast) & $>100$ \\
\hline A431 (human epidermoid) & 65 \\
\hline EC17 (human esophageal) & 82 \\
\hline EC109 (human esophageal) & $>100$ \\
\hline HCE7 (human esophageal) & $>100$ \\
\hline TT (human esophageal) & 68 \\
\hline Ms-1 (human SCLC) & 47 \\
\hline HT-29 (human colon) & $>100$ \\
\hline Lovo (human colon) & 42 \\
\hline SW480 (human colon) & 30 \\
\hline HL-60 (human leukemia) & 15 \\
\hline Jurkat (human T cell leukemia) & 21 \\
\hline
\end{tabular}


$3 Y 1$ and NIH3T3 cells up to $100 \mu \mathrm{g} / \mathrm{ml}$, whereas it decreased the growth rate of oncogene-expressing NIH3T3 cells. In addition, hematopoietic cells such as human leukemia HL-60 and human T cell leukemia Jurkat cells displayed increased sensitivity to migrastatin compared with other solid tumors.

Tumor cells can survive and grow under anchorageindependent condition, which is the hallmark of

Fig. 3. Effect of migrastatin on Ms-1 growth.

(a)

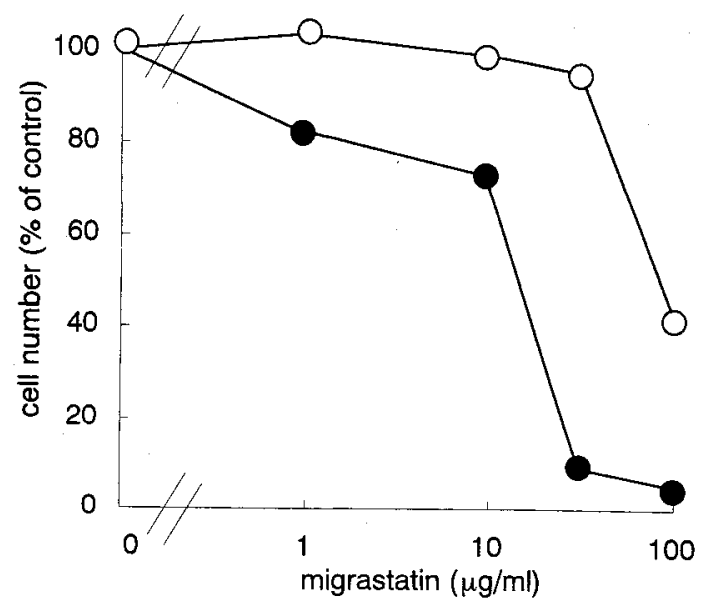

(b)

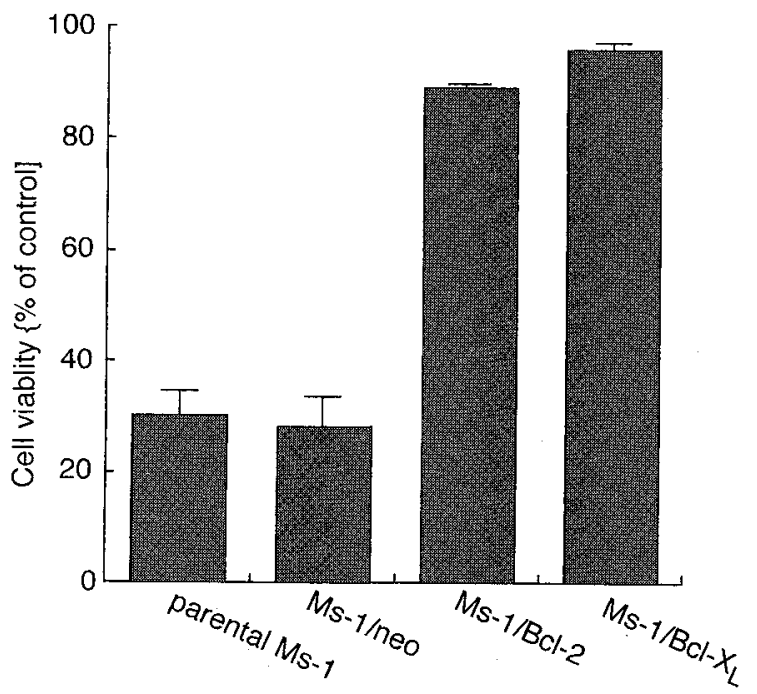

(a) Ms- 1 cells $\left(5 \sim 6 \times 10^{3}\right.$ cells $/ 96$-well plate) were incubated under anchorage-dependent (open circle) or anchorage-independent (closed circle) conditions with various concentrations of migrastatin for 4 days. Cell growth was assessed using MTT.

(b) Parental Ms-1 cells, Bcl-2-overexpressing Ms-1 cells (Ms-1/Bcl-2), Bcl- $\mathrm{X}_{\mathrm{L}}$-overexpressing $\mathrm{Ms}-1$ cells (Ms-1/Bcl- $\mathrm{X}_{\mathrm{L}}$ ) or vector control (Ms-1/neo) cells were treated with $100 \mu \mathrm{g} / \mathrm{ml}$ of migrastatin for 3 days. Cell viability was assessed by trypan blue dye exclusion assay. malignancy in tumor cells. Therefore, we next examined the effect of migrastatin on the growth ability of human small cell lung carcinoma Ms-1 cells under anchorageindependent conditions, and compared it to that under anchorage-dependent conditions. Ms-1 cells were seeded on plastic dishes or antiadhesive polymer (Poly-HEMA) ${ }^{6}$ ) coated dishes in the presence of various concentrations of migrastatin, respectively, and after 4 days, the cell numbers were measured by MTT assay. Under anchorage-dependent conditions, migrastatin did not significantly reduce the growth rate up to $30 \mu \mathrm{g} / \mathrm{ml}$ (Fig. 3a), and $100 \mu \mathrm{g} / \mathrm{ml}$ of migrastatin induced cell death as evaluated by trypan blue dye exclusion assay (Fig. 3b). In addition, this cell death was inhibited by the overexpression of anti-apoptic protein, Bcl-2 or Bcl- $\mathrm{X}_{\mathrm{L}}$ in Ms-1 cells (Fig. 3b). On the other hand, migrastatin $(1 \sim 100 \mu \mathrm{g} / \mathrm{ml})$ inhibited the cell growth of Ms1 cells under anchorage-independent conditions in a dosedependent manner (Fig. 3a). Thus, migrastatin reduced the anchorage-independent growth ability of Ms-1 cells. The growth rate of Ms-1 cells under anchorage-independent condition was lower than that under anchorage-dependent condition (data not shown). However, because many anticancer drugs tested such as adriamycin, vinblastine or camptothecin showed similar inhibitory effects in two culture conditions (data not shown), selective growth inhibitory effect of migrastatin seen in anchorageindependent conditions should not be due to this different growth rate in two conditions. Integrin-signaling is thought to be involved in both cell migration ${ }^{7)}$ and anchorageindependent growth ${ }^{8)}$, therefore, effect of migrastatin on integrin-signaling should be studied.

\section{Acknowledgments}

We thank Dr. H. OSADA and Dr. S. Simizu for supplying Bcl$\mathrm{X}_{\mathrm{L}}$ cDNA. We also thank Dr. M. YoshidA for supplying rafNIH3T3 cells and Ha-ras-NIH3T3 cells. This study was partly supported by grants from the Ministry of Education, Culture, Sports, Science and Technology of Japan.

\section{References}

1) Nakae, K.; Y. Yoshimoto, T. Sawa, Y. Homma, M. Hamada, T. TAKEUCHI \& M. Imoto: Migrastatin, a new inhibitor of tumor cell migration from Streptomyces $\mathrm{sp}$. MK929-43F1. Taxonomy, fermentation, isolation and biological activities. J. Antibiotics 53: 1130 1136, 2000

2) UmezaWa, K.; I. B. Weinstein, A. Horwitz, H. Fujiki, T. Matsushima \& T. Sugrmura: Similarity of teleocidin B and phorbol ester tumor promoters in effects on membrane receptors. Nature 209: 411 413, 1981

3) Yamashita, T.; M. Imoto, K. Isshiki, T. SAWA, H. NaGanaWa, S. KurasaWa, B-Q, Zhu \& K. UmeZaWa: 
Isolation of a new indole alkaloid, pendolmycin, from Nocardiopsis. J. Natl. Prod. 51: 1184 1187, 1988

4) Nakae, K.: Y. Yoshimoto, M. Ueda, T. Sawa, Y. TAKahashi, H. NaganaWA, T. TAKEUChI \& M. IMOTO: Migrastatin, a novel 14-membered lactone from Streptomyces sp. MK929-43F1. J. Antibiotics 53: $1228 \sim 1230,2000$

5) Fukata, Y.; N. Oshiro, N. Kinoshita, Y. Kawano, Y. MatsuoKa, V. BenNetT, Y. MatsuURA \& K. KaIBUChI: Phosphorylation of adducin by Rho-kinase plays a crucial role in cell motility. J. Cell. Biol. 145: 347 361,
1999

6) Fukazawa, H.; S. Mizuno \& Y. Uehara: A microplate assay for quantitation of anchorage-independent growth of transformed cells. Anal. Biochem. 228: 83 90, 1995

7) Sieg, D. J.; C. R. Hauck, D. Ilic, C. K. Klingbeil, E. Schaefer, C. H. DAMsky \& D. D. Schlaepfer: FAK integrates growth-factor and integrin signals to promote cell migration. Nature Cell Biol. 2: 249 256, 2000

8) Frisch, S. M. \& E. RuOSLAHTI: Integrins and anoikis. Curr. Opin. Cell Biol. 9: 701 706, 1997 